WAVES OF KNOWING 


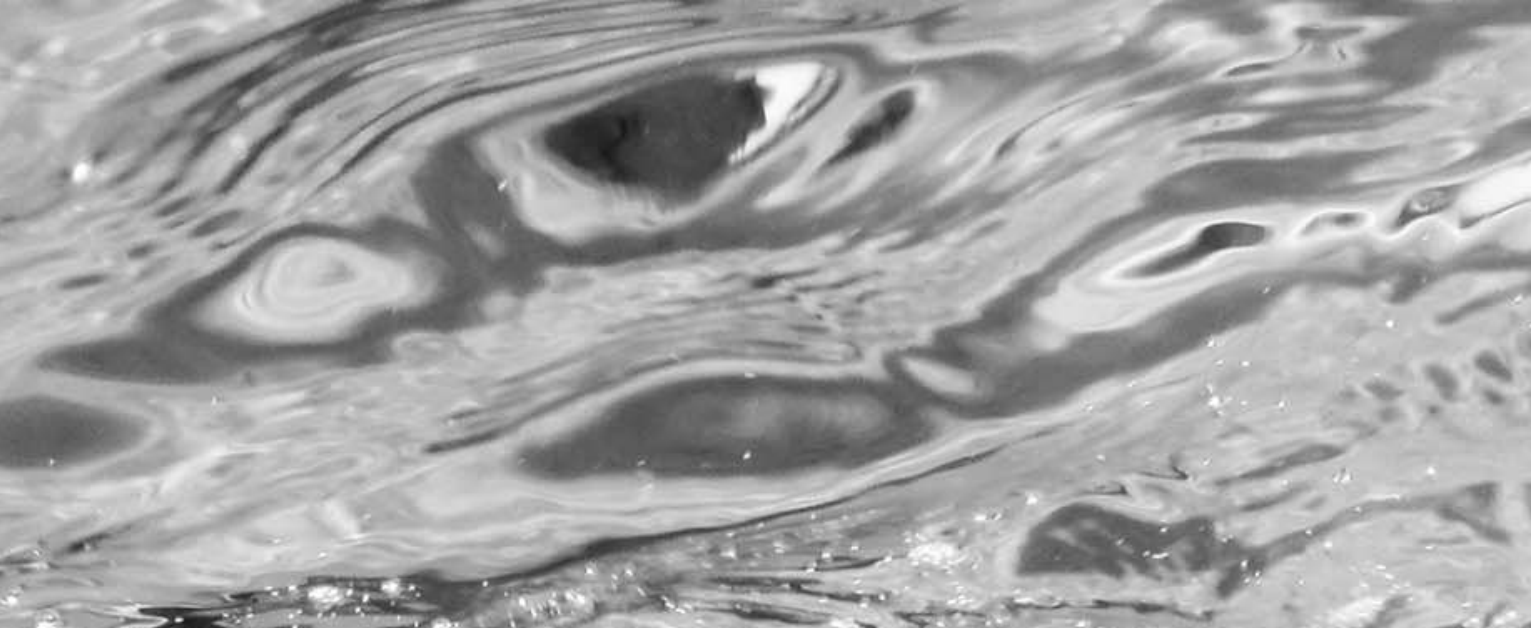

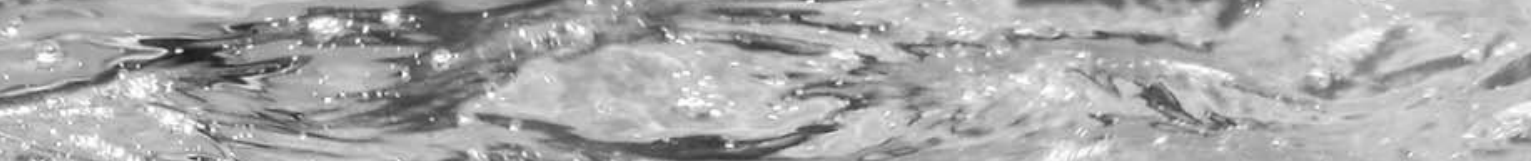

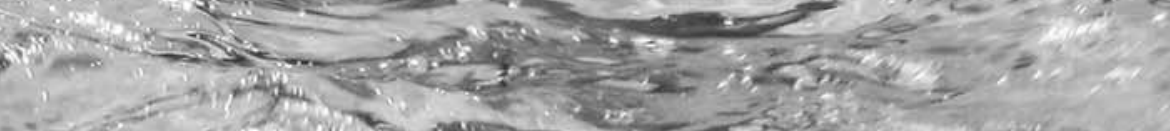



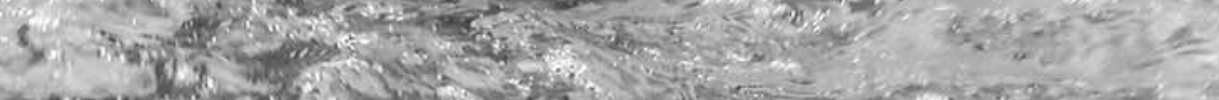

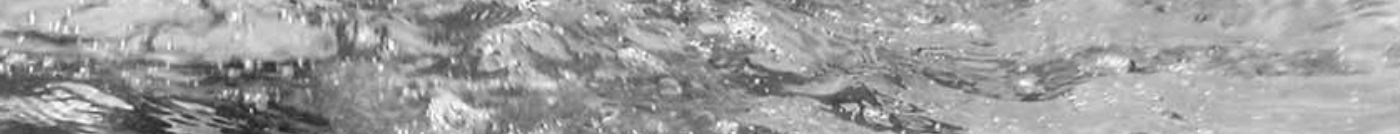

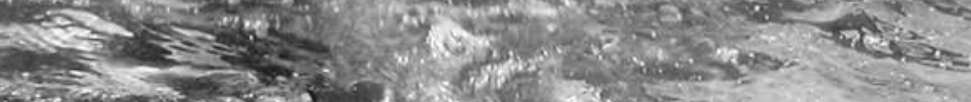
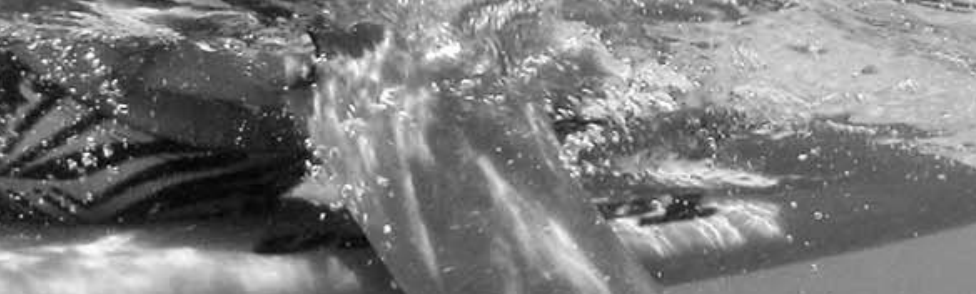

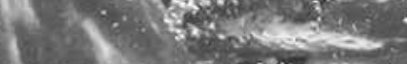



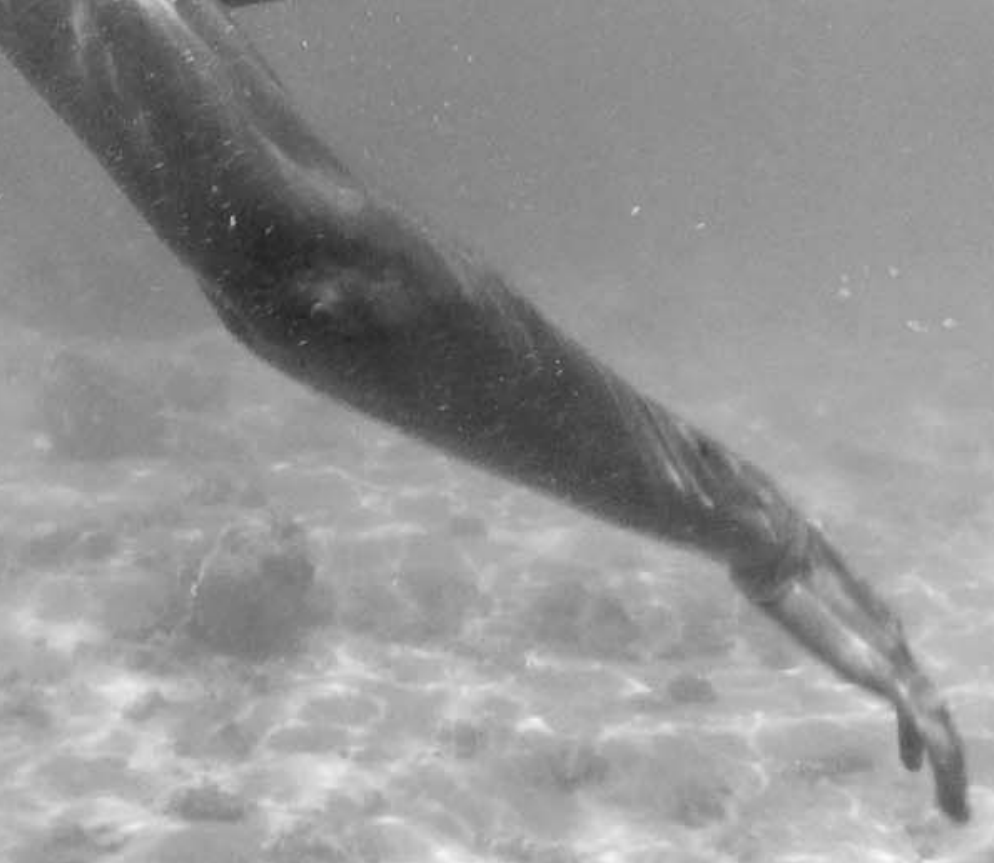


Karin Amimoto Ingersoll

\section{WAVES OF KNOWING}

\section{A Seascape Epistemology}

Duke University Press Durham and London 2016 
(C) 2016 DUKE UNIVERSITY PRESS. All rights reserved Printed in the United States of America on acid-free paper $\infty$ Designed by Courtney Leigh Baker Typeset in Arno Pro by Copperline.

Library of Congress Cataloging-in-Publication Data Names: Ingersoll, Karin E.

Title: Waves of knowing : a seascape epistemology / Karin Amimoto Ingersoll.

Description: Durham : Duke University Press, 2016.

Includes bibliographical references and index.

Identifiers: LCCN 2016007858 (print) | LCCN 2016008644 (ebook)

ISBN 9780822362128 (hardcover : alk. paper)

ISBN 9780822362340 (pbk. : alk.paper)

ISBN 9780822373803 (e-book)

Subjects: LCSH: Hawaiians. | Surfing-Hawaii.

Classification: LCC DU624.65 I69 2016 (print) | LCC DU624.65 (ebook) | DDC $305.899 / 42-\mathrm{dc} 3$

LC record available at http://lccn.loc.gov/2016007858

Cover art: Abigail Lee Kahilikia Romanchak, Watermark (detail), collagraph. Courtesy of the artist. 
This book is dedicated to my two boys, Kahoe King and Nāhe'olu Clive.

You both are the inspiration for my heart's work and happiness. 
